\title{
FMTVDM $^{\circledR}{ }^{\circledR}$ Provides the First True SPECT and PET Quantification and Not Virtual Guesstimation Produced by SUV and Extraction Fraction, Yielding First Accurate Theranostic Method
}

\section{Richard M. Fleming*}

The Chamelot Foundation, FHHI-Omnific Imaging-Camelot, USA

"Corresponding author: Richard M. Fleming, The Chamelot Foundation, FHHI-Omnific Imaging-Camelot, USA, E-mail: rmfmd7@yahoo.com

Received date: September 06, 2018; Accepted date: September 17, 2018; Published date: September 24, 2018

Copyright: @2018 Fleming RM. This is an open-access article distributed under the terms of the Creative Commons Attribution License, which permits unrestricted use, distribution, and reproduction in any medium, provided the original author and source are credited.

\section{Editorial}

Dr. Arif Sheikh is Professor and Co-director of Cardiac Nuclear Imaging, Department of Radiology, Division of Nuclear Medicine, Molecular Imaging and Theranostic at Temple University, Lewis Katz School of Medicine. Dr. Sheikh has an extensive background both academically and in research making him eminently qualified to write on this topic of "quantification" in Nuclear Imaging, including Nuclear Cardiology and Oncology fields.

His brief overview walks physicians, clinicians and research scientists through the field discussing the efforts made to date to provide "virtual" quantification using SUV $\mathrm{max}_{\max }$ and first pass extraction up to the modern development of FMTVDM ${ }^{\odot \odot}$. The failure of these other methods to provide True Quantification has limited PET and SPECT imaging.

The development of "The Fleming Method for Tissue and Vascular Differentiation and Metabolism $\left(\mathrm{FMTVDM}^{\odot{ }^{\circledR}}\right.$ ) using same state single or sequential quantification comparisons" as Dr. Sheikh notes, provides the FIRST Truly Quantitative method for differentiating tissue measuring changes in regional blood flow [1] and metabolism differences. It requires a critical calibration step (The Fleming Method/ TFM), which is part of the patent, to assure this accuracy, consistency and reproducibility yielding True Quantification [2].

Even since Dr. Sheikh's review, this journal has published the verification paper [3] following the initial VA Study [4] demonstrating FMTVDM $^{\odot \odot}$ as the first "stress-first/stress-only/stress-stress" imaging method reducing patient radiation and costs; saving time, money and lives. These publications [3,4] immediately precede the 2018 ASNC Conference in San Francisco [5] where the findings will be released for nuclear cardiologists. These results for nuclear cardiac MPI follow the multiple publications where FMTVDM ${ }^{\odot \odot}$, using the Breast Enhanced

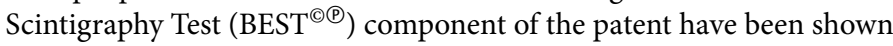
to provide the same True Quantification for diagnostic and treatment purposes for cancer diagnosis and treatment, beginning with breast cancer [6-9].

With the initial VA Pilot study now recently published [4] followed by the Multi Center USA and Asia trial [3], FMTVDM ${ }^{\odot \odot}$ is now being licensed for clinical use. FMTVDM ${ }^{\odot \odot}$ has now demonstrated its clinical usefulness both for finding the actual extent of coronary artery disease and the extent of an individual's development of cancer. FMTVDM $^{\odot ®}$ and $\mathrm{BEST}^{\odot \odot}$ not only provide earlier diagnosis of heart disease and cancer, including breast cancer, but by finding the transition states between healthy and critical disease, it places the patient on a "Health-Spectrum"॰
It is this Truly Quantitative capability of FMTVDM ${ }^{\odot ®}$ to do more than just guess qualitatively yes you have disease or no you don't that makes it unique, changing the Standard of Care for Nuclear Cardiology and Nuclear Medicine/Oncology. FMTVDM ${ }^{\odot \odot}$ tells you where you lie on the "Health-Spectrum." No individual goes from having no disease to being critically ill. Yes/No tests cannot do this. There is clearly a transition process, which happens, which has not been detectable or measureable previously and FMTVDM ${ }^{\odot \odot}$ accurately, consistently and reproducibly measures these actual changes in tissue.

Because FMTVDM ${ }^{\odot \odot}$ accurately, consistently and reproducibly measures this, it means we can now for the first time also measure whether your treatment is working by testing you with FMTVDM ${ }^{\odot \odot}$, then provide a treatment to you and repeating FMTVDM $^{\odot \odot}$ to measure if the treatment worked or needs to be changed, thereby saving precious time, money and lives.

To do this exciting "patient-oriented/patient-specific/patientdriven" diagnosis and treatment for both heart disease and cancer, beginning with breast cancer, we have started the exclusive not-forprofit licensing and further expansion of the use of FMTVDM ${ }^{\odot \odot}$ and $\mathrm{BEST}^{\odot \oplus}$ through the assistance of HugsAmerica.org. Hugs America is a not-for-profit foundation begun by actress Angela Watson. With her help and Hugs America we will be implementing FMTVDM ${ }^{\odot \odot}$ and

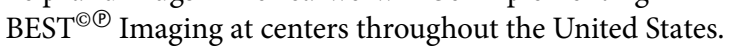

\section{References}

1. Fleming RM, Angina and Coronary (2003) Ischemia are the result of coronary regional blood flow differences. J Amer Coll Angiol 1: 127-142.

2. Fleming RM, Fleming MR, McKusick A, Chaudhuri T (2018) FMTVDMTFM(P): True quantification requires standardization of the tool being used to measure, with a known, unchanging standard to produce accurate, consistent and reproducible quantified measurements. J Nucl Card.

3. Fleming RM, Fleming MR, McKusick A, Chaudhuri T (2018) Multicenter clinical trial confirms FMTVDM๑ $\odot$ MPI in seven modern clinical laboratories in the USA and Asia. Artificial intelligence (AI) with true quantification. J Nucl Med Radiat Ther 9: 4.

4. Fleming RM, Fleming MR, Harrington G, McKusick A, Chaudhuri T (2018) USVAH Study demonstrates statistically significant improvement in diagnosis and care of U.S. veterans using FMTVDM-FHRWW $(\mathcal{P}$ quantitative nuclear imaging. The era of truly quantitative stress-first, stress-only imaging has begun! J Nucl Med Radiat Ther S09 : 006.

5. Fleming RM, Fleming MR, Dooley WC, McKusick A,Chaudhuri T (2018) FMTVDM@ P Provides the First Nuclear Quantitative Method for Nuclear Cardiology and Introduces a New Era for Nuclear Cardiology 25th Annual scientific session of the american society of nuclear cardiology: Bridging quality imaging and patient care San Francisco, USA: 206-07. 
Citation: Fleming RM (2018) FMTVDM ${ }^{\odot \odot}$ Provides the First True SPECT and PET Quantification and Not Virtual Guesstimation Produced by SUV and Extraction Fraction, Yielding First Accurate Theranostic Method. J Nucl Med Radiat Ther 9: e118. doi: $10.4172 / 2155-9619.1000 \mathrm{e} 118$

Page 2 of 2

6. Fleming RM, Fleming MR, Dooley WC, McKusick A (2018) FMTVDMBEST(P) Breast cancer imaging eliminates the fear of having BRCA1 and BRCA2 breast cancer genes. J Clin Mol Med 1: 1-2.

7. Fleming RM, Dooley WC, Chaudhuri TK (2017) The development of FMTVDM-best imaging(®): The answer for breast cancer. breast enhanced scintigraphy test (BEST@(P): quantifying the detection of breast cancer and its treatment. J Nucl Med Radiat Ther 8: 350.
8. Fleming RM, Dooley WC (2002) Breast enhanced scintigraphy testing distinguishes between normal, inflammatory breast changes and breast cancer. A prospective analysis and comparison with mammography. Integr Cancer Ther 1: 238-245.

9. Fleming RM (2004) Breast enhanced scintigraphy test demonstrates improvement in breast disease after daily consumption of soy protein. J Nutr 134: 1262s. 